\title{
Opening the Door of Memory with a Camera Lens
}

The Folk Memory Project and Documentary Production

\section{Wu Wenguang}

Translator. Stacy Mosher

\section{OpenEdition}

\section{Journals}

Electronic version

URL: http://journals.openedition.org/chinaperspectives/6584

DOI: 10.4000/chinaperspectives.6584

ISSN: 1996-4617

\section{Publisher}

Centre d'étude français sur la Chine contemporaine

\section{Printed version}

Date of publication: 25 November 2014

Number of pages: $37-44$

ISSN: 2070-3449

\section{Electronic reference}

Wu Wenguang, «Opening the Door of Memory with a Camera Lens», China Perspectives [Online],

2014/4 | 2014, Online since 01 January 2017, connection on 28 October 2019. URL : http:// journals.openedition.org/chinaperspectives/6584 ; DOI : 10.4000/chinaperspectives.6584 


\title{
Opening the Door of Memory
}

\section{with a Camera Lens}

\author{
The Folk Memory Project and Documentary Production (1)
}

The following text is an introduction to the Folk Memory Project (Minjian jiyi jihua), a multidisciplinary memory initiative aiming at producing textual and visual records of the historical experience of rural populations, especially during the Great Leap famine. Written by its founder, independent documentary filmmaker Wu Wenguang, the article presents the project and the works of individual filmmakers, four years after its launch. It provides an account of the work method and goals of a specific unofficial memory project, which is further discussed in the article "Performance, Documentary, and the Transmission of Memories of the Great Leap Famine in the Folk Memory Project" pp. 17-26.

\section{Beginning to remember}

$\mathrm{O}$ ne by one, people carrying hand-held digital video cameras (DVs) infiltrated villages scattered throughout the Shandong-Hebei plains, the hills of Hunan and Hubei, and the mountains of Yunnan. The villages they returned to were all related to them in some way, and they'd gone to visit elderly people in crude, dimly-lit rural houses in an attempt to record the memories buried deep inside their hearts. For these elderly villagers, this was the first time that someone had sat in front of them with a camera, waiting for them to open their memory trove and pull out events from the distant past.

This all happened in 2010 as part of the Folk Memory Project (FMP) initiated by the Caochangdi Workstation. More than 20 participants returned to their villages to film interviews with elderly people and record their recollections of the past. The first door of memory opened onto the three-year Great Famine that occurred 50 years ago (from 1959 to 1961). For this reason, the project was initially called the Hunger Project, and a direct motivation was to "take to the road because of hunger."

The "hunger memories" of 50 years ago have long constituted a blank space in official histories, emerging only occasionally in the form of scattered words and phrases sounding like little more than hearsay in the conversations of elderly people who experienced it. The young people who set out to track down these "hunger memories" 50 years later, like the "standard youth" of this era, have been constrained by official textbooks to a macroenvironment of "turning their backs on history and only looking forward." The vast majority of them were not only completely cut off from the "hunger history," but had almost no knowledge of China's true history during the 30 years following 1949. The pallidness and poverty of historical memory and a sense of uncertainty and confusion in the present have created a "spiritual hunger," and this group of people set off on their journeys in hopes of satisfying this hunger. This Hunger Project was the first phase of what one year later came to be known as the Folk Memory Project.
Most of these wayfarers were young people born in the 1980s or later. Some were recent college graduates aspiring to create documentary films; others were college students with a special proclivity for documentaries; and others were former villagers with no university or arts background who had come to the cities to work, and who voluntarily set off on the same path to "seek out memories of hunger" out of a basic conception that "recording present reality requires facing the historical past, especially the hidden and overlooked history of ordinary people."

Unlike the usual method of "seeking out subject matter or source materials for creative productions," this group of travellers headed for villages to which they were closely connected, for example where they were born and raised, or where their parents had been born and raised, or where their grandparents lived.

The emphasis on "their own villages" meant returning to a place where they had roots but which they had abandoned; to places they were most able to call their own in present reality. Their initial move after returning to their villages was to open the "first door of memory" by recording old people's memories of the three-year famine.

These elderly villagers, ever the "insignificant" and the "most voiceless," had always maintained their silence, no matter how tragic and painful their lives - in the past as well as the present. For this reason, history as they experienced it was likewise unspoken and blank. The returnees were therefore returning to the unspoken and blank, to the ordinary, and to common knowledge. Another important point was that returning to the villages in this way was not merely for the purpose of documentary production or a one-time "material-gathering safari" or "helicopter-style field investigation" with "withdrawal upon achieving the objective"; it was a process of planting their feet firmly on the ground, taking in the local essence, engaging in creation at the same time as participation, and combining their understanding of society with self-transformation. It was not only the documentary that

1. This document was first published under the title "'Minjian jiyi jihua' zhong de da jihuang jilupian" in Twenty-first Century (Ershiyi shiji), No. 2, 2014 


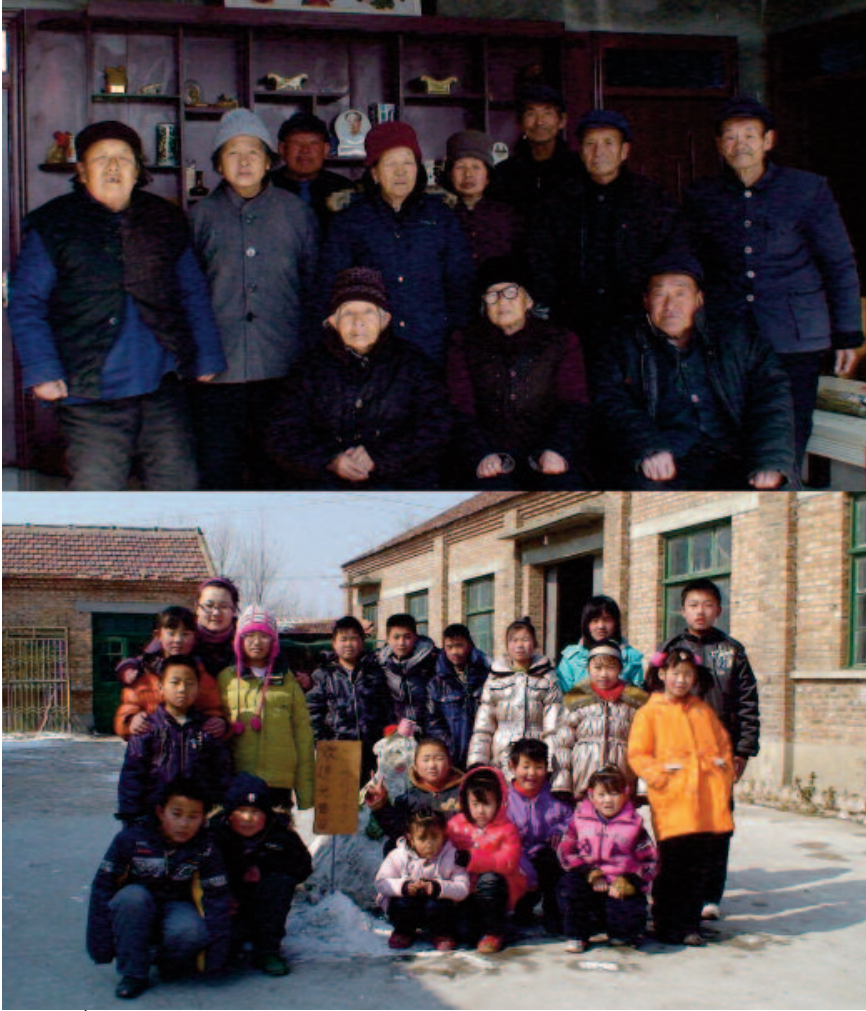

Photo 1 - Elderly and children in Zou village. @ Zou Xueping

was the work of art; the creator himself or herself was also a work in a constant state of self-training and self-moulding.

This was an encounter. In their search for elderly people with long-submerged histories, these young people had to bridge the ignorance of their parents' generation regarding the Great Famine. This meeting of grandparents and grandchildren spanned the mnemonic void of an entire generation, like creeping through a long, dark tunnel inevitably filled with mire, pits, and swamps, always in danger of being crushed. Exploring the crossroads of present reality and history was likewise an adventure, and in the process there were experiences and stories, chance meetings, surprises, and snags; there were sighs and sudden realisations, there were times of getting lost, and there were setbacks, searches for needles in haystacks, and rays of hope in the darkness... Traversing the dark tunnel of historical memory involved an arduous trek through endless rugged patches in the murky present. The experiences of the memory-seekers, encountered for the first time and difficult to replicate, inevitably included those memories hidden in the deepest recesses, which became the glittering gold flecks of countless possibilities in their documentary production.

\section{Entering a village of hunger and surfeit}

Zou Xueping returned to Zoujia Village in Shandong's Yangxin County. She was born and raised there, but with her graduation from high school and admission to a fine arts college she fulfilled the wish of both her parents and herself to leave the village, Heavens be praised, and she'd had nothing more to do with the place apart from visiting family during the Spring Festival. Since joining the Folk Memory Project in 2010, however, Zou Xueping has extended her home visits to two or three months every year. The first documentary Zou Xueping completed, The Starving Village (Ji'e de cunzi, 2010, 76 min.), selected narratives from interviews she'd done with her vil- lage's elders regarding the Great Famine, as well as the last two years she spent with her grandmother. At the beginning of the film, an elderly woman in her 80s, Zou Xueping's grandmother, is sitting alone in an empty room, eating, sleeping, staring into space, talking to herself, speaking of the past and of her own impending death... The film flows gradually through the inertia of this elderly woman's life, weaving in the scenery and other elderly villagers to create a sense of stark seclusion and silence and of being completely cut off from the rest of the world. Elderly people, their faces etched with the passage of time, enter the frame, sit down in their homes against a backdrop of walls covered with old, yellowed newspapers and New Year pictorials, old suitcases, old-fashioned bedding on the kang, and begin telling stories of their hunger 50 years ago.

The next year (2011), Zou Xueping returned to her village and showed her documentary The Starving Village to the elderly people she'd interviewed and their families. The old people were overjoyed and grateful that someone from the village's younger generation had cared enough to film their stories of the past. When the filmmaker asked what they thought of "the film being shown in other places and even overseas," however, they responded that it could be shown in China, because what they'd said was all true, but it shouldn't be shown overseas, because it would be "embarrassing to China and make foreigners ridicule our country." Similar "opposition" arose within the filmmaker's own family. Her parents, born in the 1950s, her brother and sister-in-law, born in the 1970s, and her younger brother, born in the 1990s, all opposed Zou Xueping continuing with the FMP, including shooting this kind of documentary. They all felt that it was "dangerous," would lead her into "error," and was not a "proper occupation." During another film screening for the village's "youngest generation," ranging in age from eight years old to their teens, an 11-year-old girl raised a surprisingly similar concern: "I'm afraid foreigners will ridicule us Chinese." And she harboured a fear that no one so young should know: "What if the government comes looking for the filmmaker and accuses them of a crime?"

Fortunately, Zou Xueping also had supporters in the village. Her nine-yearold niece, the daughter of her elder brother, was the only one in Zou Xueping's family who supported her, and there were also some old people who supported her interviews and filming. One of them had a particularly strong reaction, saying that he completely disagreed with the view that "the film shouldn't be shown overseas." Apart from expressing his views to the filmmaker, he took her to see some of the old people with opposing views and kept reasoning with them one-on-one until they abandoned their "opposition." The film's story is recounted amidst this kind of "obstruction" and "head-on opposition," presenting the current reality of the village to us. It tells us about the reality encountered 50 years after the Great Famine, when it has not yet "been remembered"; the hunger that still remains in the present "Satiated Village"; the dreadfulness of this hunger, which involves more than the stomach and intestines; the even more troubling appearance of "satiation" in the later generations who never experienced the history of hunger and whose education in actual history is lacking...

Zou Xueping's first two years returning to her village were propelled by the need to finish her two documentaries. But as she gradually brushed away the thick dust coating the village's history and memories, present reality came brutally to the fore. The rural scene thus interwoven from past and present formed a gigantic magnetic field that kept Zou Xueping returning to the village over the next two years. Zou Xueping subsequently completed Children's Village (Haizi de cunzi, 2012, 85 min.) and Trash Village (Laji de cunzi, 2013, 82 min), which became part of her Zoujia Village Tetral- 
ogy. The four films can be seen as the trajectory of the filmmaker's return to her village to approach memory, followed by her groping exploration of present reality, as well as a self-portrait of her life from the age of 25 to 29.

\section{The pitfalls of history and present reality}

Zhang Mengqi, a dance school student who went on to continue her training at a dance college, might have expected to become a professional dancer after graduation, since everything she'd learned up until then was related to dance. If conditions and luck allowed, she might even try creating her own dance compositions. And in fact, after graduating from college in 2008, Zhang Mengqi followed this path before studying video production just as the Folk Memory Project was beginning. Her maiden work, Self-Portrait with Three Women (Zihuaxiang he san ge nüren, 2010, 70 min.), related stories and memories of her adolescence and from her inner being explored the interwoven fates of three generations of women. When she joined the FMP, she chose a village both close to and remote from her. Her father was born there but left in the early 1980s to live in the city, as a result of which Zhang Mengqi also became an urbanite. Her father's decision to permanently turn his back on this impoverished and closed-off village in Hubei's Suizhou Mountains, and on the parents and brothers who remained there, was only a dim memory from her youth. Now Zhang Mengqi was returning to that village, called Diaoyutai, setting off on a path of discovery that set her utterly apart from her dance school classmates and friends.

Zhang Mengqi's film Self-portrait: at 47 km (Zihuaxiang: 47 gongli, 2011, $77 \mathrm{~min}$.) starts off with a shot of a mileage post marked " $47 \mathrm{~km}$." The marker is located along a national highway at the spot where a gravel road leads off to the village that the filmmaker is about to enter. This scene signifies that the filmmaker is entering a village whose name has been replaced with a mileage marker, a village neglected and forgotten by an "outside world developing at full speed." Like countless other villages scattered throughout this vast country, Diaoyutai has been neglected and forgotten in terms of both its past and its present. Zhang Mengqi initially entered this village to seek what had been forgotten, including her own grandfather and the "hunger memories" of 50 years before, but also today's elderly residents, "enduring their twilight years" in dreary loneliness and boredom.

The first elderly person to appear in the film is the filmmaker's grandfather, who was naturally the first person she visited upon returning to the village. This 78-year-old man, who gropes through his daily business during daylight and then spends his nights around his fire pit, is deaf, making conversation extremely difficult. When he finally understands that the granddaughter who has appeared before him wants to hear about the three-year famine, his first response is apprehension, followed by dissuasion: "Don't make a fuss about the people who starved to death in 1959. If you aren't careful, this country has a regulation that if you say the wrong thing, you're committing an error..."

The next elderly person who is asked about his memories is almost stone deaf. Even when his grandson shouts into his ear, he still has a hard time communicating the request to "talk about the three years of hunger."

Question: Did you suffer from hunger in 1959 ?

Old man (looking confused): What? I can't hear you.

Question (shouting the key year): 1959... 1959.

Old man: Drink wine?

The question was rephrased: "The time of 'tiding over'"...

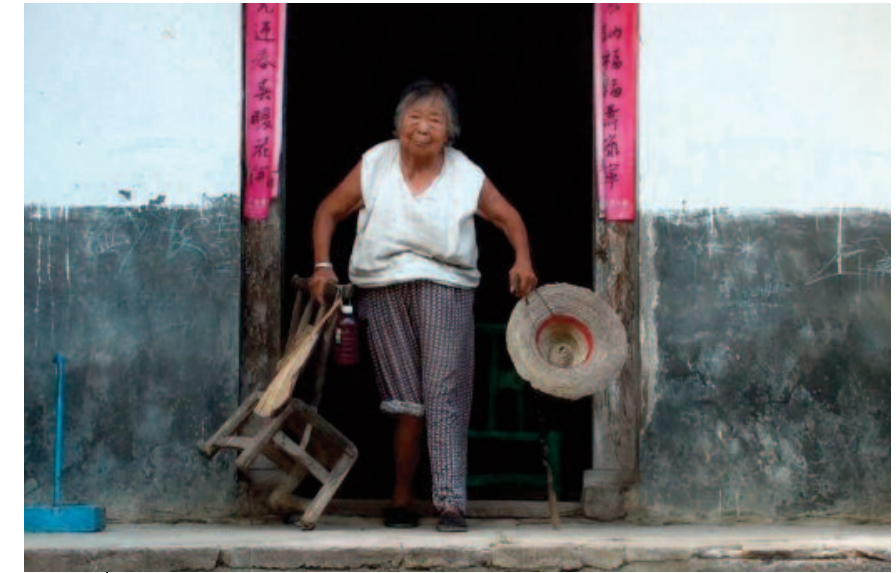

Photo 2 - The Barefoot doctor in Zhang Mengqi's Self-portrait: at 47 km (Zihuaxiang: 47 gongli, 2011, 77 min.). (C) Zhang Mengqi

When he hears the official expression "tiding over," the old man's eyes light up, and he bursts out: "Oh, that was in 1959. I ate chaff and peanut leaves, cotton plant leaves - I ate anything. In 1959 I had it rough! I suffered back then. My brothers starved to death..."

Another elderly person appears, not deaf, but lame, and she brings a bamboo chair with her, taking one step and then moving the chair. Once the village's "barefoot doctor" (what village doctors were called 30 years ago), she brought many of the village's residents into the world and ushered some out of it. Sitting before the filmmaker's camera, she remembers "those three years": rushing out to save someone at death's door by finding something that could be cooked into porridge; a villager told to make rice for a gathering of cadres, then told to eat what was left over so the masses wouldn't see it, gobbling it down and then swelling up and dying; her own daughterin-law so hungry she ate the cottonseeds inside her pillow and became constipated, using sticks to prod the excrement from her anus...

Countless old people take their place one after another before the camera and recount their memories of the three years of hunger: eating all kinds of wild herbs, thinking of every means to survive, some dying as the last mouthful of food reaches their lips, dying on the road as they search for food, even shoes being stewed...

Some of the old people, like the filmmaker's deaf grandfather, still fear that "complaining" will bring them trouble. Their memories of hunger are distinct from beginning to end, but equally indelible are their fearful recollections of the "historical experience" of "committing error by doing this sort of thing." The film presents a brutal juxtaposition of old people facing the camera and relating their hunger memories while sitting in solitude around their fire pit in winter as something cooks in a pot, or lying incapacitated on a pile of cotton batting against dilapidated, age-blackened walls in homes that sometimes don't even have electrical supply.

A filmmaker who inserts herself into the present reality of this " $47 \mathrm{~km}$ " village cannot avoid certain pitfalls: alienation, coldness, suspicion, rejection... The film also states the filmmaker's follow-up questions: What does this village have to do with me? What do its past and its memories have to do with my present reality? Why did I have to return to this place? Are there secrets buried deep inside this village? What is the fate and future of the villagers who live here generation after generation? 
These questions cascade like dominos. What Zhang Mengqi herself may not have foreseen when she first returned to the village in 2010 was that she would keep coming back, producing a third film, Self-portrait: Dancing at $47 \mathrm{~km}$ (Zihuaxiang: 47 gongli tiaowu, 2012, $77 \mathrm{~min}$.), and a fourth film, Self-portrait: Dreaming at 47 km (Zihuaxiang: 47 gongli zuomeng, 2013, 77 min.). A 24-year-old dancer who had "cast off all relations" with this village, Zhang Mengqi managed, by entering the village and approaching the old people and the distant events buried within them, to draw near to a brutal and surreal rural present.

\section{A villager's memoirs: Tracing the memories of the older generation}

Luo Bing is a former fine arts student and modern art aficionado enamoured of concepts and big words, but underneath his "artsy youth" garb is a rural youth from a village called Luo (2) in Hunan's Chaling County. The Folk Memory Project made Luo Bing's return to his village different from countless past visits, when he'd "returned" for the Spring Festival and to

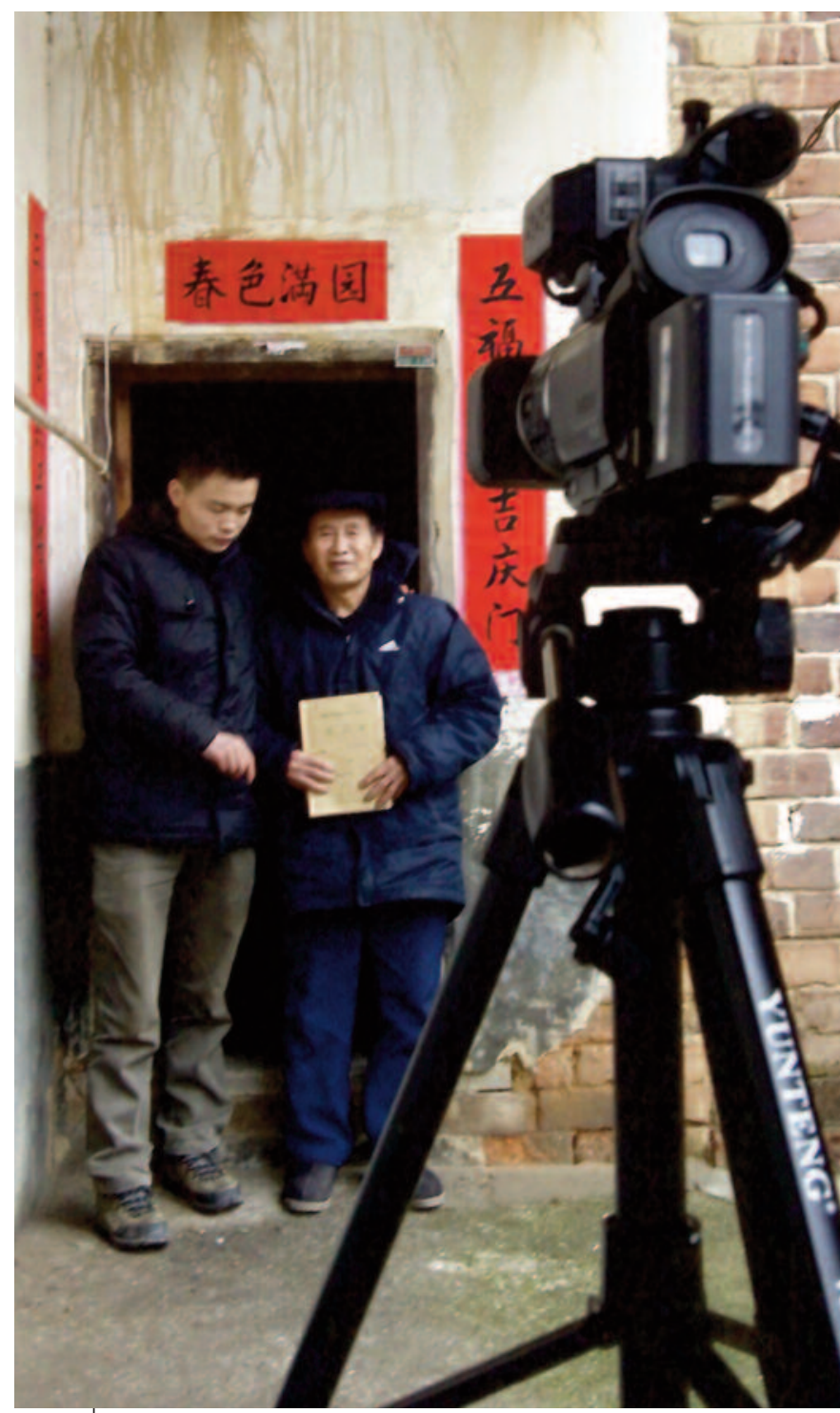

Photo 3 - Luo Bing and Ren Dingqi in Luo Village: Pitiless Earth and Sky (Luojiawu: tiandi wu qing, 2012, 75 min.). (C) Luo Bing visit relatives as a matter of habit and obligation with little choice involved. This time he was going back to seek out old people and their memories, to get a new measure of this little village where he was born and raised, and to become reacquainted with the village's people, its houses, trees, dogs, and cattle.

The Luo Bing who returned this time was different from the fine arts student who only cared about art, concepts, and terminology. His first discovery was a secret that shocked him: an old man next door, apparently no different from anyone else, had spent ten years writing his memoirs. This old man, Ren Dingqi, was 78 , had only a primary school education, and had spent his entire life as a farmer in the village. Starting in 1994, he began recording his life experiences in the exercise books his children and grandchildren had left behind, ten notebooks in all totalling 300,000 words, in serial style with a total of 54 chapters. The memoir begins with his birth and then relates his experience of the War of Resistance, the Civil War, Liberation, Land Reform, the formation of agricultural cooperatives, the People's Communes, the Great Leap Forward, the Great Famine, and the Cultural Revolution, and ends in the early 1980s with reform and opening. The title of the book is A Ruthless World.

The memoirist seemed to have some lingering fear of revealing his memories of a life tossed in the vicissitudes and political turmoil of his times, and he didn't quite trust his young neighbour Luo Bing, only allowing him to look at the table of contents and treating his manuscript like an "internal document." Luo Bing's attempts to gradually draw closer to the memoirist became the first step in approaching other elderly people upon his return, and he discovered many secrets he'd known nothing about buried deep in this place where he'd been born and raised.

This process of "approach and discovery" constituted the narrative thread of Luo Bing's first completed film, Luo Village: I and Ren Dingqi (Luojiawu: wo he Ren Dingqi, 2011, $80 \mathrm{~min}$.), and what it drew out was the reason for Ren Dingqi's worries about giving Luo Bing access to his memoirs: "Have we reached a time when we can speak openly?" "In 1957 they called on us to freely air our views, but then we got in trouble for it." While worried, this elderly man eagerly took Luo Bing to interview other elderly people, including a man who had been a village leader during the three-year famine (and who refused point-blank to talk with him).

The former village leader was not the only villager who continued to harbour worries, fears, and refusal over making "tragic memories" known; even Luo Bing's own grandmother, and younger people who hadn't experienced hunger, instinctively worried. In one scene in the documentary that leaves a particularly deep impression, a villager named Yu Maoli is willing to talk to Luo Bing about hunger, and in the shot where the old man is remembering it, a voice comes from outside the frame; his daughter (in her 40s) is preventing her father from talking, saying it will make things difficult for his children. The obstructing voice persists, harsh and intransigent, and in the camera's lens, the father who finds his recollections so rudely interrupted falls silent and becomes still as a statue.

At the end of the film, the memoirist Ren Dingqi finally brings out his manuscript for Luo Bing to read. The deeper implication of this ending to Luo Bing's first film is that his second documentary will continue its exploration of the interweaving of history and the present in this village. The next year, Luo Bing returned to the village, carrying out interviews on history while also shooting footage. In his second film, Luo Village: Pitiless Earth

2. TN: This village's full name is Luojiawu. 
and Sky (Luojiawu: tiandi wu qing, 2012, 75 min.), the memoir in which the old man Ren Dingqi records 50 years of his life is opened page by page: the tumult of Land Reform in 1949, being labelled a landlord family, his father dead and his home destroyed, leaving the family destitute... the $1958 \mathrm{Great}$ Leap Forward, being driven like herds of cattle to build a reservoir... the even more disastrous three-year famine beginning in 1959, malnourished and resorting to wild herbs and tree leaves... the Cultural Revolution in 1966, more than 30 years old but still unwed because of his landlord status, constantly on guard against public criticism, a ten-year nightmare...

In the film, Luo Bing not only reads his elderly neighbour's historical memoir, but also types it out and has it printed in book form, bringing it back for the villagers to read together. A memoir produced by someone from the village is not only the writer's personal story, but also the shared experience of villagers of his generation. When the book is circulated among the villagers, it prompts in some cases sighs of profound gratitude for the memories it calls forth, in other cases indifference over things that happened long ago and don't need to be written about, and in yet other cases fear that putting these things down in black and white will lead to retribution if another inescapable political campaign arises. The memoirist's younger brother is one of those holding this last view.

Situated in Luo Village, where memories are still habitually covered up, Luo Bing faces the elderly memoirist Ren Dingqi, who "took the initiative to record his own life" with an instinctive desire to "bear witness," proving that not everyone chooses to forget, even a villager with no channel for expressing his views. The memoirist Ren Dingqi is an exception in this village, someone who became more exceptional with age. Will the young man who encountered him, Luo Bing, become the exception in Luo Village's new generation?

\section{Remembrance draws in a variety of participants}

The Folk Memory Project began with a "trial attempt" in the summer of 2010. Entering the "hunger memories" of 50 years ago, participants discovered among the elderly residents of their villages a history of hunger that had been concealed and neglected, while also feeling a "hunger" for history as well as an even more terrifying "spiritual hunger" in the present, which provoked a need for a protracted return-to-the-village movement. From then on, every winter became the regular time for participants to return to their villages, while at the same time the project began pulling in participants with different backgrounds and identities.

Li Xinmin is a young female worker who moved to the city from Huamulin, a stockaded village located deep in a mountain forest of Yunnan's Fengqing County. Li had discontinued her studies after primary school because her family couldn't afford the 88 yuan in school fees, and she began working at the age of 15 . When she was 18 , Li began working at the Caochangdi Workstation as a cook and cleaner, and in her spare time she learned how to type on a computer. The second year after the FMP began, Li felt that she also had a village and wanted to take part, so she learned basic filming techniques and then returned to her home village in Yunnan. To the surprise of many, Li Xinmin didn't just play around with a single return to her village, but continued her visits over the course of four winters, interviewing more than 20 old people and producing a documentary trilogy: Back to Huamulin (Huidao Huamulin, 2011, 75 min.), Huamulin 2012 (Huamulin 2012, 2012, 75 min.), and Huamulin: Boy Xiaoqiang (Huamulin,

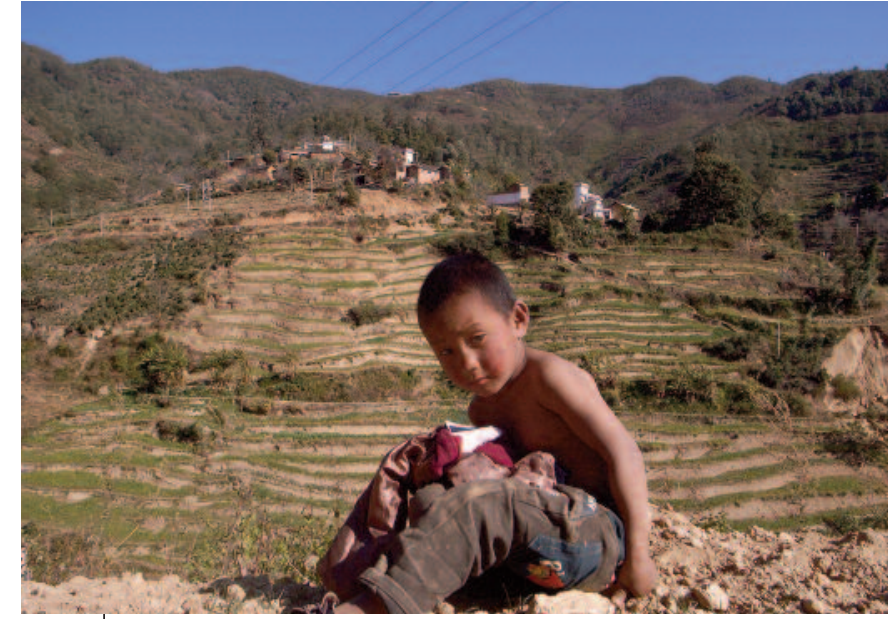

Photo 4 - Screen grab from Li Xinmin's Huamulin: Boy Xiaoqiang (Huamulin, Xiaoqiang ah Xiaoqiang, 2013, 76 min.) (C) Li Xinmin

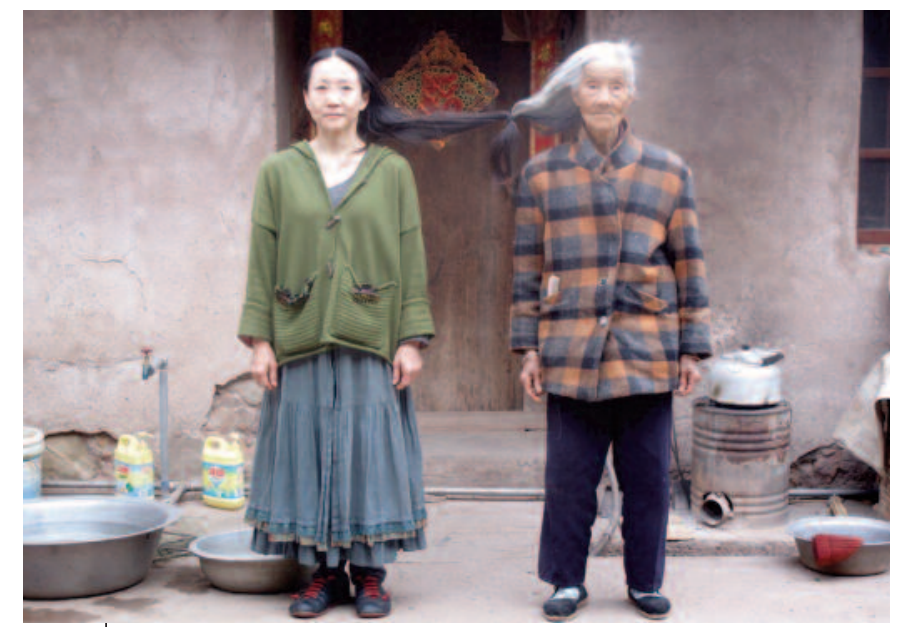

Photo 5 - Screen grab from Wen Hui's Listening to Third Grandmother's Story (Ting San Nainai jiang guoqu de shiqing, 2011, 75 min.). Wen Hui is on the left, with her Third Grandma on the right. @ Wen Hui

Xiaoqiang ah Xiaoqiang, 2013, 76 min.). The old people interviewed in that stockaded village brought out their painful memories of the three-year famine, but also their laments over what they found hard to endure in the present: still needing to work despite failing vision; a 50-year-old son still not married; bedridden with illness and ignored by offspring, wondering where the casket would come from...

One participant who differs from the younger participants in terms of age, experience, and profession is Wen Hui. After working in dance theatre for nearly 20 years, she found her own village to return to: Daheyan in Chuxiong, Yunnan Province, the home of an elderly woman she called Third Grandma, her father's aunt. This woman had gone unmentioned until the death of Wen Hui's father, who from 1949 onward had taken pains to conceal his "landlord family background" and effectively cut off history at that point. After 50 years immersed in city life and dance, Wen Hui made her first foray into this village she knew nothing about and found Third Grandma, her only surviving relative from her grandparents' generation. Her attempts to resurrect her forcibly truncated family history resulted in a film called Listening to Third Grandmother's Story (Ting San Nainai jiang guoqu de shiqing, 2011, 75 min.). The old woman's wrinkled face appears, only one 


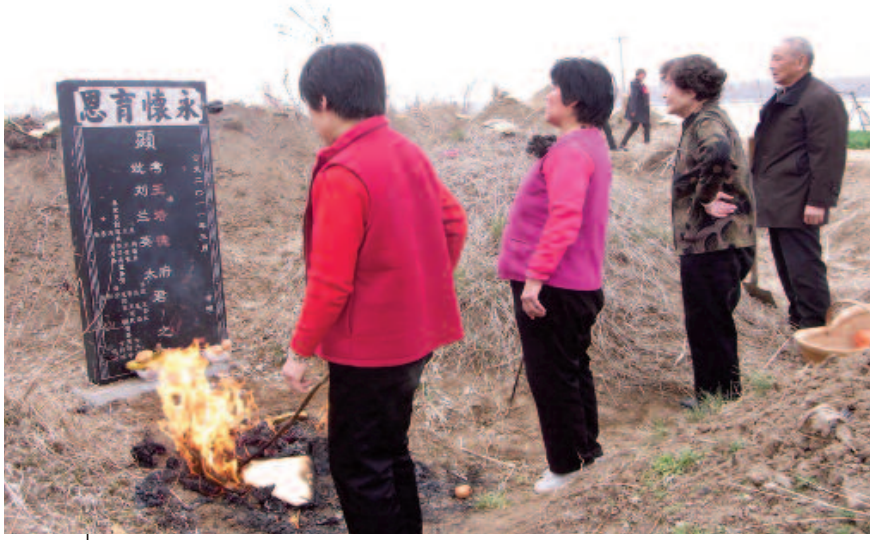

Photo 6 - Screenshot from Wang Hai'an's Believing in Zhanggao Village (Xinyang Zhanggao cun, 2012, 86 min.). (c) Wang Hai'an

tooth remaining but eyes still bright as she recalls events of the last 60 years as distinctly as if they were yesterday: Land Reform, her family's land redistributed, even their tables, chairs, and quilts taken away, grandfather imprisoned, grandmother strung up and beaten, mother committing suicide, fear of speaking out turning her into a virtual mute...

Jia Zhitan, 63, is one of the oldest participants in the Folk Memory Project. The biggest difference between him and other participants is that he himself is a villager from a place called Jimingqiao in Shimen County, Hunan Province, where he grows oranges and tangerines for a living. Jia Zhitan became involved in the FMP through a previous project of the Caochangdi Workstation, the China Village Documentary Project, which began in 2005. After becoming one of ten village filmmakers in this earlier project, Jia Zhitan continued making films, and it was only natural for him to transition from the China Village Documentary Project to the Folk Memory Project, which also involved filming in the village. Turning his lens to his village's historical memory as someone who has spent most of his life there, Jia Zhitan has an obvious advantage over the younger returnees as an "old villager" who has been on the ground for 63 years. He has interviewed more than 100 of his village's elderly about their memories touching on the first three decades after 1949, including Land Reform, the Great Leap Forward, the Great Famine, and the Cultural Revolution. The old people recall the Cultural Revolution, when during the 1970 "one strike and three antis" campaign dozens of the village's residents were investigated, imprisoned, and tortured in connection with fabricated "counterrevolutionary clique incidents." This portion of the village's historical memory inspired jia Zhitan's documentary Revolution in Baiyun Village ('Yi da san fan' zai Baiyun, 2012, 80 min.). In this film, lia's multiple identities of spectator, witness, and current historical investigator permeate the film from beginning to end. His searching lens brings each of the "persecutors," "victims," and countless "onlookers" of those years into the scene of memory one by one, revealing the tip of an iceberg of tragic persecution of villagers by their fellow villagers 40 years before.

The Folk Memory Project moves forward in "snowball fashion"; as films have been produced and shown in various film festivals, arts spaces, or universities, and as "The Folk Memory Project and Documentary Production" has become a teaching subject in some universities and arts institutes, even more young people and students have joined in by returning to their home villages during the winter break to interview elderly people about their memories and shoot documentary films, in some cases giving rise to new documentary filmmakers. Wang Hai'an and Shu Qiao were second-year students at the Tianjin Academy of Fine Arts when they first joined the FMP in 2010 and volunteered to go back to their villages to interview elderly people and shoot footage. Wang Hai'an returned to Zhanggao Village near Qingzhou, Shandong Province, and Shu Qiao returned to Shuangjing Village in Hunan's Xupu County. They had been born and raised in these villages, but since entering college they'd only gone back once a year for family visits. After joining the FMP, they began taking video cameras back with them to do interviews and shoot footage. Of course it takes more than one trip back to complete a documentary; it's a sustained act requiring patience, tenacity, and self-discipline to get results. Neither of these young people has stopped participating, and they continue to carry out interviews and shoot footage every year, along with engaging in practical action such as collecting news and statistics on people who died in the Great Famine and a campaign to erect a stone tablet in the village. Upon graduating two years later in 2012, each of them finished their first documentaries, Wang Hai'an's Attacking Zhanggao Village (Jingong Zhanggao cun, 2012, 86 min.) and Shu Qiao's Shuangjing, I'm your Crandson (Shuangjing, wo shi ni de sunzi, 2012, 78 min.). After graduation, they chose to stay at the Caochangdi Workstation and continued returning to their villages to carry out interviews and shoot footage, and the next year, both completed their second films, Wang Hai'an's Believing in Zhanggao Village (Xinyang Zhanggao cun, 2012, 86 min.) and Shu Qiao's Shuangjing, I Want to Marry You (Shuangjing, wo yao jia gei ni, 2013, 74 min.).

Guo Rui is another example. When she learned about the Folk Memory Project in early 2012, she was a third-year graduate student at Nankai University majoring in historical research. She returned to the village where her father was born, Daguo Village in Linying County, Henan Province, and began interviewing elderly people and shooting footage. This was Guo Rui's first attempt at combining specialised historical study with field investigation of the memories of the village's old people, and it was also her introduction to documentary production. After completing her graduate studies, Guo Rui didn't continue studying for her PhD or begin looking for a job, but chose to continue returning to the village and exploring the village's history during the Great Famine. An investigative thread that she's followed throughout is the grandfather she'd never met and who had been a village cadre 50 years ago - what kind of person was he during the Great Famine? What had he done? At the end of the film, the filmmaker finds her grandfather's grave among the weeds, and the last shot is of her grandfather's tombstone, a blank tablet. The shot pans away from the tombstone and fixes on the face of the person holding the camera, Guo Rui. This was Guo Rui's maiden work, Grandfather, great famine (Yeye de jihuang, 2013, 75 min.).

\section{In-depth exploration: Rebuilding the countryside while making a film}

The first draft of this article was written in mid-2012. At that time, the Folk Memory Project had been ongoing for two years and could be regarded as the beginning stage of a trial project. This current version of the article was revised in early 2014, by which time the project was entering its fourth year, and the introduction of new content has brought new changes. One point that the project established from the outset and has continued to implement is that participants continue returning to their villages for about three months every winter. Continuing to return to the villages every year 
and interview elderly people about their memories is the basic activity that has not changed, while every year some new activities have been added.

The Memory Project's point of departure was that "returning to the village is not only to collect material for a documentary." The documentary filmmaker is a discoverer of truth, a self-examiner, and a critic, and at the same time a recorder and salvager of the forgotten, hidden, and neglected histories of ordinary people. In fact, returning to the scene of history also enmeshes the filmmakers in a current reality filled with contradictions and disputes and all types of conflict. These returnees find it difficult to be nothing more than "cool-eyed recorders" who can "keep their feet clean by standing outside the quagmire of the village's current reality." Each return to the village is not a one-time action, but rather a multiply reiterated or even perpetual motion in which the returnee inevitably becomes a "participant in transforming present reality."

From the first return to a village in 2010 , the focus of the project has been to film interviews with elderly people about their memories. The three-year famine was the first topic, and going along with the old people's memories, the project extended its content to other historical periods, including Land Reform, the Great Leap Forward, the Socialist Education Movement, and the Cultural Revolution. During the interviews, many old people remember family members and fellow villagers who starved to death. What were the names of those starvation victims? How old were they? Shouldn't this information be recorded and these people commemorated? Some topics like this consequently became the focus of follow-up and discussion after participants returned from the villages, and the following year when they went back to the village they included a program of "statistics and information on those who died during the famine," and set up tombstones in the villages for the famine victims. As activities devoted to the villages' present reality progressed, they were shocked by realities such as the lack of support and care for elderly people, and the catastrophic accumulations of garbage. During the third winter of returning to the villages (2013), filmmakers began to implement an "elderly assistance foundation project" to help elderly people who were ill and lacking support, and also led village children in cleaning up rubbish. By the time they returned to the villages in early 2014, they had perceived the reality of children left behind in the villages and the lack of public cultural buildings, so they began leading village children in building village libraries. The idea is to use the library as a base for reading, book discussions, and film viewings, as well as for teaching children how to film the memories of old people, and to teach dance, singing, and art. The long-term plan is that building a library and launching cultural activities will lead to the establishment of a public space in the village.

It could be said that returning to the village each year is like sowing seeds or reclaiming wasteland. In the process of constantly pushing forward the Folk Memory Project, the returnees' original status as amateur recorders of history and documentary filmmakers begins to take on the quality of builders and participants in the village's present reality. This merging of multiple identities also challenges each participant to choose how to position him- or herself in dealing with society: as a "pure" or "less than pure" film creator? As someone who is "removed from the world" or who "enters the world"?

In real life, of course, the questions and answers aren't so black and white, but they serve as coordinates embedded in the FMP. It then becomes an experimental method of walking on the "two legs" of intervention in social reality and the act of creation. Moving forward in this way, one senses the dust of history that has accumulated for so many years, the frozen quagmire of current reality that cannot be thawed overnight, the height and incomparable solidity of the walls of the present, the pitfalls ever present beneath one's feet, the difficulty of changing and building, but in the process, a consensus gradually becomes clear: present social reality cannot be changed in the short term, but self-transformation can begin here and now.

Casting oneself into the vortex of reality - confronting, participating, and becoming entangled in it - leads to all kinds of unexpected encounters and stories, and experience, realisation, and reflection follow as the process tunnels deeper and leaps forward. All of this melds into a rich fodder for documentary production and ensures that a documentary filmmaker will continue creating. Looking back on the past four years of the Folk Memory Project, all of the initial participants have produced their maiden documentary films, and some have even completed four films, for example Zou Xueping's four-part "Village Series" and Zhang Mengqi's "Self-portrait" tetralogy, while others have completed two or three films that also constitute a series. As of 2013, 12 participants had completed a total of 26 documentaries.

The participants in the FMP are not only these people; as of early 2014, more than 130 individuals had participated at various times, carrying out interviews with more than 1,000 elderly people in 19 provinces and more than 200 villages. These interviews, images and texts are now being transcribed and placed on the Folk Memory Project Blog to become part of a future Memory Archive.

How much can actually be remembered? How far and how deeply can this method of participatory construction of the countryside combined with filming documentaries continue? There is no way to predict any of this; it is just a start, or rather an infinite ongoing attempt, a snowball method that pulls in countless people as it pushes forward; it may run its course, or it may keep going indefinitely.

\section{Translated by Stacy Mosher.}

I Wu Wenguang is a documentary filmmaker. In 2005, he founded an art centre, Caochangdi Workstation (草场地工作站), with the choreographer Wen Hui.

The website of the Folk Memory Project is accessible here: http://blog.sina.com.cn/ccdworkstation. 


\section{Appendix: Folk Memory Project Filmography, 2010-2014}

\section{The list below presents the completed documentaries of the artists in residence participating in the FMP, as well as works of other filmmakers produced in the frame of this project.}

Guo Rui 郭睿, Grandfather, great famine 爷爷的饥荒Yeye de jihuang, 2013, 75 min.

Guo Rui 郭睿, The Rivers and Sisterhood 河流与女人的吟唱 Heliu he nüren de yinchang, 2014, 72 min.

Hu Tao 胡涛, Old People and My Village 山旮旯 Shan Ga La, 2013, 70 min.

Jia Nannan 贾楠楠, My Grandpa's Winter 贾夫奎的冬天 Jia Fukui de dongtian, 2011, 30 min.

Jia Zhitan 贾之坦, Revolution in Baiyun Village “一打三反" 在白云 "Yi da san fan" zai Baiyun, 2012, 80 min.

Jia Zhitan 贾之坦, I Want to Be a People's Representative 我要当人民代表 Wo yao dang renmin daibiao, 2013, 78 min.

Jia Zhitan 贾之坦, Wo dang zhengfu jianduyuan 我当政府监督员 Wo dang zhengfu jianduyuan, 2014, 71 min.

Li Xinmin 李新民, Back to Huamulin 回到花木林 Huidao Huamulin, 2011, 75 min.

Li Xinmin 李新民, Huamulin 2012 花木林 2012 Huamulin 2012, 2012, 75 min.

Li Xinmin 李新民, Huamulin, Boy Xiaogiang 花木林, 小强阿小强, Huamulin, Xiaoqiang ah Xiaoqiang, 2013, 76 min.

Li Xinmin 李新民, Huamulin zhi bei 花木林之碑 Huamulin zhi bei, 2014, 70 min.

Luo Bing 罗兵, Luo Village: I and Ren Dingqi 罗家屋: 我和任定其 Luojiawu: wo he Ren Dingqi, 2011, 80 min.

Luo Bing 罗兵, Luo Village: Pitiless Earth and Sky 罗家屋: 天地无情 Luojiawu: tiandi wu qing, 2012, 75 min.

Luo Bing 罗兵, Luo Village: Farewell, Luojiang Bridge 罗家屋: 永别落江桥 Luojiawu: yongbie Luojiang qiao, 2013, 73 min.

Shu Qiao 舒侨, Shuangjing Village, I'm Your Grandson 双井，我是你的孙子 Shuangjing, wo shi ni de sunzi, 2012, 78 min.

Shu Qiao 舒侨, Shuangjing Village, I Want to Marry You 双井, 我要嫁给你 Shuangjing, wo yao jia gei ni, 2013, 74 min.

Shu Qiao 舒侨, Shuangjing Village I'm a paralyzed person 双井, 我是痽子, Shuangjing, wo shi tanzi, 2014, 78 min.

Wang Hai'an 王海安, Attacking Zhanggao Village 进攻张高村 Jingong Zhanggao cun, 2012, 86 min.

Wang Hai'an 王海安, Believing in Zhanggao Village 信仰张高村 Xinyang Zhanggao cun, 2013, 71 min.

Wang Hai'an 王海安, Poeming Zhanggao Village 诗歌张高村, Shige Zhanggaocun, 2014, 70 min.

Wen Hui 文慧, Listening to Third Grandmother's Story 听三奶奶讲过去的事情 Ting San Nainai jiang guoqu de shiqing, 2011, 75 min.

Wu Wenguang 吴文光, Investigating: My Father in 1949 调查: 1949年的父亲 Diaocha: 1949 nian de fuqin, 2013, 60 min.

Wu Wenguang 吴文光, Because of Hunger: Diary 1 by Wu 因为饥饿: 吴日记之1 Yinwei ji'e:Wu riji zhi yi, 2013, 90 min.

Wu Wenguang 吴文光, Diaocha Fuqin - Dang'anjuan 调查父亲——档案卷 Diaocha Fuqin - Dang'anjuan, 2014, 30 min.

Zhang Mengqi 章梦奇, Self-Portrait with Three Women 自画像和三个女人 Zihuaxiang he san ge nüren, 2010, 70 min.

Zhang Mengqi 章梦奇, Self-portrait: at 47 km 自画像: 47 公里 Zihuaxiang: 47 gongli, 2011, 77 min.

Zhang Mengqi 章梦奇, Self-portrait: Dancing at $47 \mathrm{~km}$ 自画像: 47公里跳舞 Zihuaxiang: 47 gongli tiaowu, 2012, 77 min.

Zhang Mengqi 章梦奇, Self-portrait: Dreaming at $47 \mathrm{~km}$ 自画像: 47公里做梦 Zihuaxiang: 47 gongli zuomeng, 2013, 77 min.

Zhang Mengqi 章梦奇, Self-portrait: The Bridge at $47 \mathrm{~km}$ 自画像: 47公里架桥 Zihuaxiang: 47 gongli jiaqiao, 2014, 77 min.

Zhang Ping 张苹, Losing Home 歸乡 Gui jia, 2014, 39 min.

Zhu Yuzhi 朱禺之, My Land and My Parents 吾土吾民Wu tu wu min, 2014, 81 min.

Zou Xueping 邹雪平, The Starving Village 饥饿的村子 Ji'e de cunzi, 2010, 76 min.

Zou Xueping 邹雪平, Satiated Village 吃饱的村子 Chi bao de cunzi, 2011, $88 \mathrm{~min}$.

Zou Xueping 邹雪平, Children's Village 孩子的村子 Haizi de cunzi, 2012, 85 min.

Zou Xueping 邹雪平, Trash Village 垃圾的村子 Laji de cunzi, 2013, 82 min.

Zou Xueping 邹雪平, Shazi de cunzi 俊子的村子 Shazi de cunzi, 2014, 80 min. 